\title{
Increased Sensitivity of Diabetic Rat Adipose Tissue towards the Lipolytic Action of Epinephrine*
}

\author{
J. Zapf, D. Feuerlein, M. Waldvogel and E. R. Froesch \\ Metabolic Unit, Dept. of Medicine, Kantonsspital Zürich, Zürich, Switzerland
}

Received: May 12, 1975, and in revised form: July 24, 1975

\begin{abstract}
Summary. Adipose tissue from streptozotocin-diabetic rats exhibits half-maximal lipolytic responses (FFA, glycerol release, increase in tissue FFA) to epinephrine at hormone concentrations 5-10 times lower than those required for half-maximal stimulation of lipolysis in adipose tissue from normal rats. The lipolytic response to epinephrine also occurs more promptly and the antilipolytic effect of insulin in the presence of submaximal epinephrine concentrations is much less pronounced than in normal tissue. In contrast, diabetic adipose tissue is less responsive to ACTH and glucagon than normal tissue. Half-maximal lipolytic responses are elicited by similar dibutyryl cyclic AMP concentrations in both tissues. Insulin treatment of diabetic rats during 24 hrs restores the lipolytic re-
\end{abstract}

sponse of their adipose tissue to epinephrine to nearly normal. Our findings point to an abnormality of diabetic adipose tissue possibly related to the hypersensitivity of catecholamines encountered in denervated organs which are adrenergically innervated. They are consistent with the present concept of different hormone discriminators on the fat cell membrane and offer a further explanation for increased FFA mobilization in the diabetic state.

Key words: Lipolysis, adipose tissue, epinephrine, ACTH, glucagon, insulin, streptozotocin-diabetes, membrane receptors, hypersensitivity.
During insulin deficiency the level of plasma free fatty acids (FFA) is elevated due to an enhanced rate of FFA release from adipose tissue $[1,2,3,4]$. Increased FFA release in this condition has been attributed to two main mechanisms: 1 . decreased re-esterification of intracellular free fatty acids [5] 2. increased activity of the hormone-sensitive triglyceride lipase [6].

In rat adipose tissue re-esterification of FFA depends entirely on the availability of glucose or glycogen to supply $\alpha$-glycerophosphate, since re-esterification due to glycerokinase is negligible $[7,8]$. Glucose uptake, however, is markedly reduced in adipose tissue of diabetic rats [9] and the glycogen stores are depleted [10]. Although glycerol release is not significantly different from that of normal adipose tissue, when expressed per fat pad or per rat [9], the imbalance between triglyceride break-down and re-esterification leads to an increased release of FFA from diabetic adipose tissue.

In the course of studies on hormone-stimulated li-

\footnotetext{
* Supported by grant No. 3.7180.72 from the Swiss National Fonds. A preliminary report of part of this work has been given at the Eighth Annual Meeting of the European Society for Clinical Investigation at Rotterdam on April 25-27, 1974 and at the Tenth Annual Meeting of the European Association for the Study of Diabetes in Jerusalem on September 11-13, 1974.
}

polysis in rat adipose tissue we found a markedly increased sensitivity of diabetic adipose tissue towards epinephrine. This finding provides an additional explanation for enhanced FFA release in the diabetic state.

\section{Materials and Methods}

Male Zbz: Cara (formerly Osborne-Mendel) rats weighing between 130 and $160 \mathrm{~g}$ were kept on NAFAG chow (No. 890, NAFAG, Gossau Switzerland) consisting of $65 \%$ cereals, $20 \%$ protein and $5 \%$ fat. They were rendered diabetic by intravenous administration of $70 \mathrm{mg} / \mathrm{kg}$ of streptozotocin and sacrificed after 4-5 days. During this time they lost between 8 and $14 \%$ of their body weight and their fat pad weight had decreased by $30-50 \%$. Their blood sugar values ranged from 360 to $540 \mathrm{mg} / 100 \mathrm{ml}(\mathrm{M} 446 \pm 62 ; \mathrm{n}=$ 70), compared with a range from 85 to $115 \mathrm{mg} / 100 \mathrm{ml}$ in the normal control animals. When diabetic rats were treated with insulin they received, during $24 \mathrm{hrs}$, 5 intramuscular injections of $2 \mathrm{U}$ each of a $1: 1 \mathrm{mix}-$ ture of Novo Actrapid and Lente insulin. 2-3 hrs after the last injection they were killed by decapitation. At this time their blood sugar levels were between 65 and $140 \mathrm{mg} / 100 \mathrm{ml}(\mathrm{M}=103 \pm 27 ; \mathrm{n}=30)$. They had regained from 5.5 to $10.7 \mathrm{~g}$ of body weight. 


\section{Incubation}

Adipose tissue was pooled as described earlier [11]. Incuabtions were carried out at $37^{\circ} \mathrm{C}$ in $3 \mathrm{ml}$ of Krebs-Ringer-bicarbonate buffer containing 30 $\mathrm{mg} / \mathrm{ml}$ of human serum albumin (dialyzed extensively at $4^{\circ} \mathrm{C}$ against several changes of distilled water and filtered by sterile filtration) and $2 \mathrm{mg} / \mathrm{ml}$ of glucose. The incubation vials were gassed for $10 \mathrm{~min}$ with $95 \%$ $\mathrm{O}_{2} / 5 \% \quad \mathrm{CO}_{2}$. In all experiments adipose tissue (150-250 mg per vial) was preincubated for $1 \mathrm{hr}$ in the absence of hormones. After that period hormone solutions $(0.1 \mathrm{ml})$ were added as indicated in the figures, and the incubation was continued for another $30 \mathrm{~min}$. Then, the incubation medium was poured through a layer of nylon stocking and collected on ice. Adipose tissue was rapidly rinsed with distilled water, blotted, transferred to $8 \mathrm{ml}$ of chloroform in $15 \mathrm{ml}$ glass-stoppered tubes and vigorously shaken for $5 \mathrm{sec}$. This procedure stopped lipolysis instantaneously.

\section{Determination of Tissue and Medium FFA}

Tissue FFA were extracted by shaking the tubes horizontally in a shaking apparatus for $30 \mathrm{~min}$ at 90 cycles per minute. The chloroform was filtered through Schleicher-Schuell folded filters (No. LS $14 \frac{1}{2} . \varnothing 10 \mathrm{~cm}$ ) and FFA were determined according to the method of Duncombe, with slight modifications [12]. The chloroform filtrates were shaken for $10 \mathrm{~min}$ with $2 \mathrm{ml}$ of copper-reagent [12] and centrifuged for $10 \mathrm{~min}$ at $1500 \mathrm{~g}$. The copper-complex on top was sucked off with a Pasteur-pipette and the chloroform phase again poured through a folded filter. All values were corrected by subtracting tissue FFA values after preincubation in the absence of hormones. Basal tissue FFA levels determined by this procedure (1.0-2.0 $\mu \mathrm{moles} / \mathrm{g}$ adipose tissue) are in good agreement with the values reported in the literature $[5,13]$. Furthermore, a second chloroform extraction of pooled adipose tissue containing different amounts of FFA yielded negligibly low values of FFA by the Duncombe method. No FFA could be detected by thin layerchromatography in the second chloroform extract. These methodological experiments indicated that more than $95 \%$ of the tissue FFA were recovered by the first chloroform extraction. Solutions of $0.1-1.2$ $\mu$ moles of oleic acid in $8 \mathrm{ml}$ chloroform served as standards.

Medium FFA were determined according to Duncombe [12] after extraction of $0.5 \mathrm{ml}$ of incubation medium with $8 \mathrm{ml}$ of Chloroform for $10 \mathrm{~min}$ as described above. All values were corrected for albumin blanks. Standard curves were run with Krebs-
Ringer-albumin buffer containing between 0.1 and $1.2 \mu$ moles $/ 0.5 \mathrm{ml}$ of oleic acid.

Glycerol in the medium was determined by the method of Eggstein and Kreutz [14]. After deproteinization with perchloric acid ( $5 \%$ final concentration) samples were neutralized with solid $\mathrm{KHCO}_{3}$, placed on ice for $30 \mathrm{~min}$ and centrifuged for $10 \mathrm{~min}$ at $4^{\circ} \mathrm{C}$ to spin down the $\mathrm{KClO}_{4}$ precipitate.

Streptozotocin was a gift from Hoffman-La Roche, Basel; crystalline porcine insulin (27 U/mg) and Lepinephrine (free base) were kindly supplied by Hoechst, Frankfurt; synthetic $\mathrm{ACTH}_{1-24}$ (Synacthen) by Ciba-Geigy, Basel. Crystalline glucagon was a gift from Eli Lilly, Indianapolis.

Dibutyryl cyclic AMP was purchased from Boehringer, Mannheim. Albumin with a FFA content of 6-12 $\mu \mathrm{eq} / \mathrm{g}$ was obtained from the Swiss Red Cross, Bern. It did not have any insulin-like or insulininhibiting effects on adipose tissue.

\section{Results}

In Fig. 1 the lipolytic response of normal and diabetic adipose tissue to various concentrations of epinephrine, ranging from $2.7 \times 10^{-9} \mathrm{M}$ to $5.4 \times$ $10^{-6} \mathrm{M}\left(5 \times 10^{-10}-10^{-6} \mathrm{~g} / \mathrm{ml}\right)$, is compared. Control values of the three lipolytic indices in the absence of added hormone were subtracted from each point (see legend to figure 1). Diabetic tissue released more glycerol and FFA than normal tissue at epinephrine concentrations below $10^{-6} \mathrm{M}$. This was most pronounced at the lowest hormone concentrations to which normal tissue did not respond. Epinephrine concentrations required for half-maximal stimulation of the three lipolytic indices as calculated from this figure are 5-10 times lower for diabetic than for normal adipose tissue. When expressed per $\mathrm{g}$ wet weight maximal release of FFA and glycerol from diabetic pads is somewhat higher, whereas maximal increase in tissue FFA is similar in both conditions. Per fat pad, per rat or per mg protein the corresponding maximal values are about 30-40\% lower for diabetic than for normal rats, since tissue wet weight of diabetic pads is considerably reduced due to enhanced triglyceride mobilization during the diabetic state.

Different reference points to which lipolytic indices may be referred would influence the relative values of the lipolytic responses, but not the affinity parameters as calculated from half-maximal stimulation.

When FFA- and glycerol release and the rise of tissue FFA are observed over a period of 30 minutes at a submaximal epinephrine concentration $(0.1 \mu \mathrm{g} / \mathrm{ml}$, 

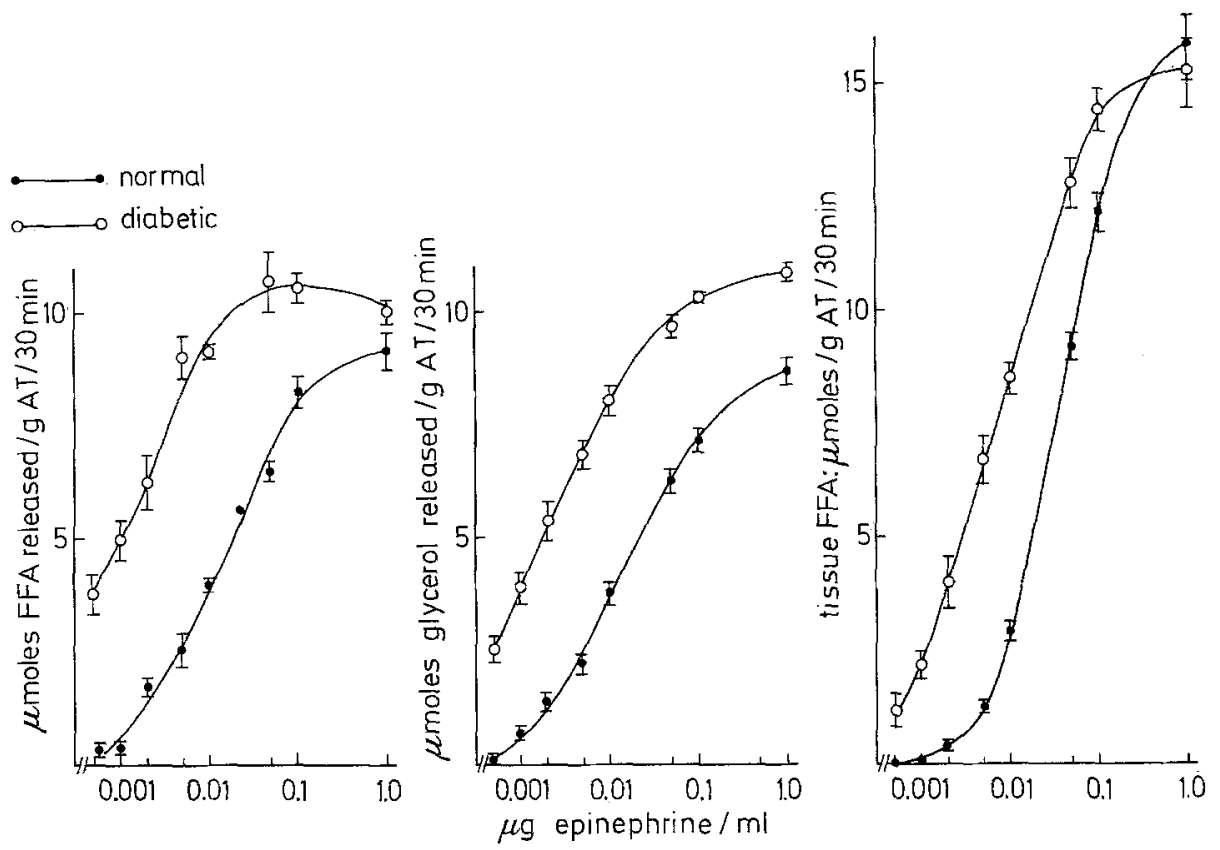

Fig. 1. Dose-response curves of epinephrine-stimulated lipolysis in adipose tissue of normal and streptocotocin-diabetic rats:

Incubations were carried out for $30 \mathrm{~min}$ at $37^{\circ} \mathrm{C}$ after hormone additions, preceded by a $1 \mathrm{hr}$ preincubation in the absence of hormone. Control values of the three metabolic indices in the absence of added hormone were subtracted: Normal adipose tissue: FFA release $0.24 \pm$ $0.13 \mu \mathrm{moles} / \mathrm{g} / \mathrm{h}, \mathrm{n}=12 ;$ glycerol release $2.9 \pm 0.14 \mu \mathrm{moles} / \mathrm{g} / \mathrm{h}, \mathrm{n}=12$. Diabetic adipose tissue: FFA release $3.6 \pm 0.43 \mu \mathrm{moles} / \mathrm{g} / \mathrm{h}, \mathrm{n}=$ 10 ; glycerol release $5.58 \pm 0.38 \mu \mathrm{moles} / \mathrm{g} / \mathrm{h}, \mathrm{n}=10$. Basal tissue FFA levels in both tissues did not change significantly during incubation; they were somewhat higher in diabetic $(2.6 \pm 0.4 \mu \mathrm{moles} / \mathrm{g}, \mathrm{n}=10)$ than in normal adipose tissue $(1.7 \pm 0.1 \mu$ moles $/ \mathrm{g}, \mathrm{n}=12)$. The points represent the mean values of 8 incubations. Bars give the SEM

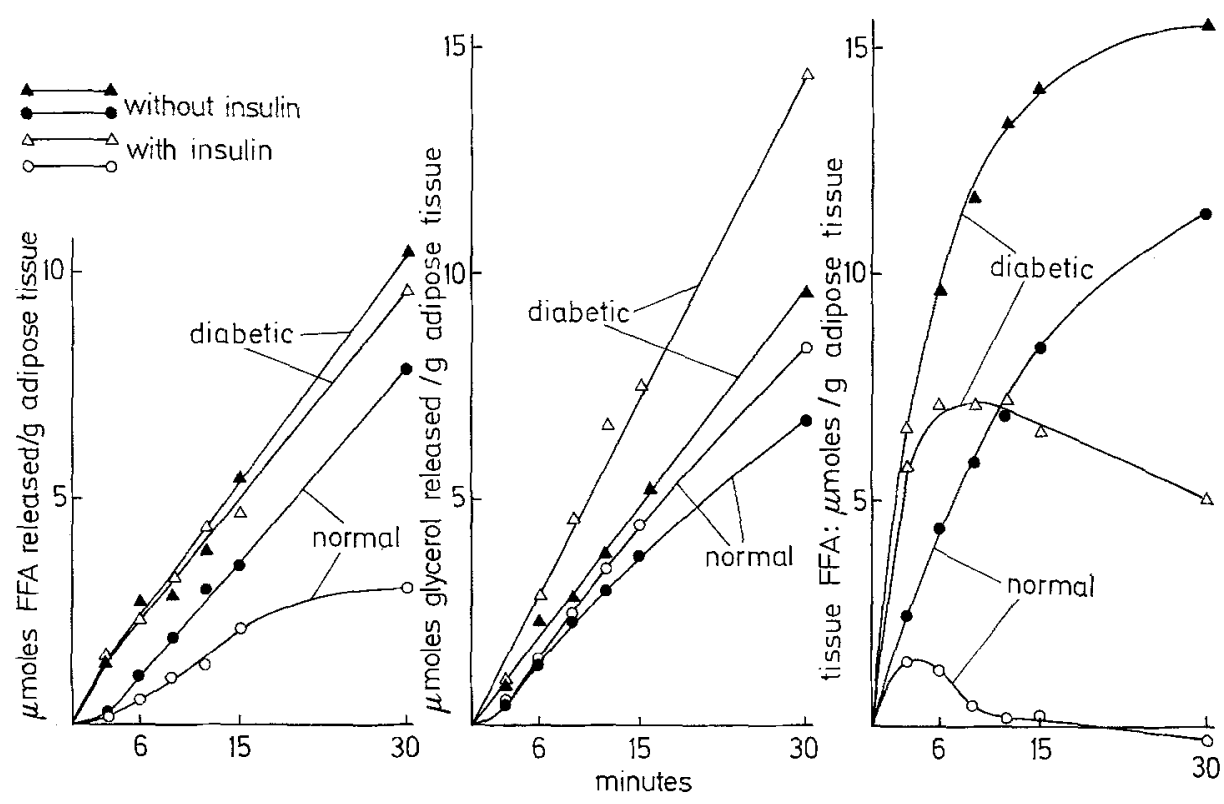

Fig. 2. Time-dependence of epinephrine-stimulated $\left(5.4 \times 10^{-7} \mathrm{M}\right)$ lipolysis in adipose tissue of normal and streptozotocin-diabetic rats in the absence and presence of $500 \mu \mathrm{U} / \mathrm{ml}$ of insulin: Points give the mean values of two different experiments. Control values in the absence of hormones have been subtracted.

Circles: normal animals

Triangels: diabetic animals 
$\left.5.4 \times 10^{-7} \mathrm{M}\right)$ a second difference between normal and diabetic adipose tissue becomes apparent (Fig. 2). In normal adipose tissue, FFA are released with a lag period of about $3 \mathrm{~min}$ after which a constant rate of FFA release is reached; in diabetic tissue the release of FFA starts immediately after addition of the hormone. Moreover, the level of tissue FFA rises much faster in diabetic tissue during the first 6 minutes. This explains the difference between the two tissues with respect to the initial kinetics of FFA release.

A third difference concerns the effect of insulin on epinephrine-induced lipolysis (Fig. 2). This difference ist most pronounced when tissue FFA are determined: in normal tissue the level of FFA returns to the baseline $10 \mathrm{~min}$ after addition of epinephrine and insulin. After a small initial rise they begin to decline after 3 $\min$. In diabetic tissue, FFA in the presence of epinephrine and insulin rise much higher, continue to increase between 3 and $6 \mathrm{~min}$, and remain elevated over the whole incubation period. Similarly, epinephrine-induced FFA release from diabetic tissue is only slightly suppressed by insulin, whereas, in normal tissue, insulin alsmost completely stops epinephrineinduced FFA release after 30 minutes.

In agreement with the findings of Jungas and Ball [15] epinephrine-induced glycerol release from either tissue is further stimulated by insulin in the presence of glucose. In diabetic adipose tissue this stimulatory effect of insulin is twice that in normal tissue. Relative re-esterification rates in the presence of insulin calculated from these experiments are about $20 \%$ lower in diabetic than in normal pads, which is compatible with the finding that glucose uptake is reduced in diabetic fat pads even in the presence of insulin [9].

Figs. 3 and 4 show the lipolytic response of adipose tissue from normal and diabetic rats to different concentrations of ACTH (Fig. 3) and glucagon (Fig. 4). FFA and glycerol release expressed per $\mathrm{g}$ wet weight are similar or even lower in diabetic tissue at low concentrations of these two hormones. The tissue FFA response to both ACTH and glucagon is lower in diabetic than in normal fat pads. Concentrations of the two hormones required for half-maximal stimulation of lipolysis are higher in diabetic than in normal tissue. This is in sharp contrast to the results shown in Fig. 1 for epinephrine-induced lipolysis.

Lipolysis induced by epinephrine, ACTH and glucagon has been shown to be mediated by stimulation of adenylate cyclase $[16,17]$ and by a corresponding increase of the level of intracellular cyclic AMP [16, $18,19]$. Therefore, the response of normal and diabetic adipose tissue to different concentrations of dibutyryl cyclic AMP was tested. Dibutyryl cyclic AMP mimicks the physiological effect of lipolytic hormones; it

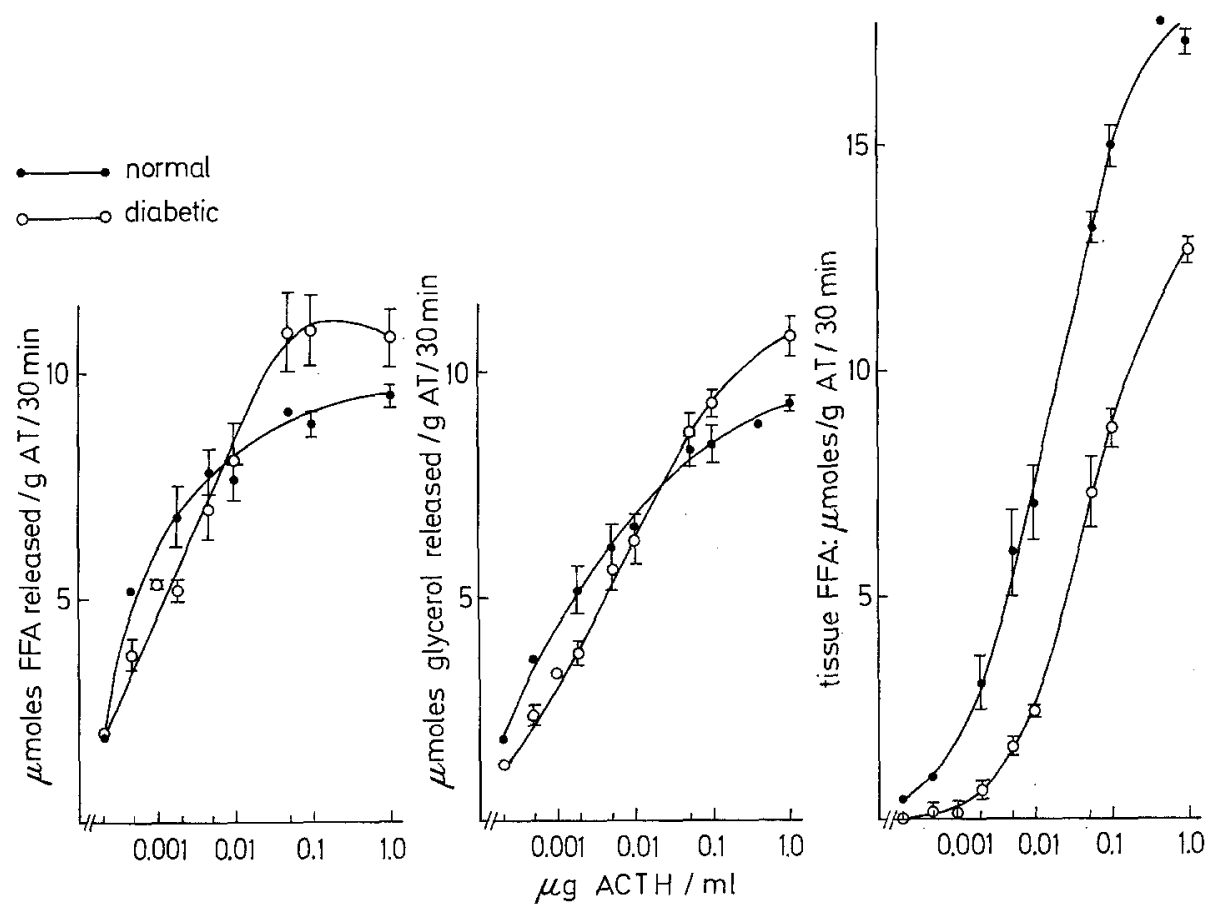

Fig. 3. Dose-response curves of ACTH-stimulated lipolysis in adipose tissue of normal and streptozotocin-diabetic rats: Incubations were carried out for $30 \mathrm{~min}$ at $37^{\circ} \mathrm{C}$ after a 1 hour preincubation period after which the different amounts of hormone were added. Each point represents the mean value of 4 incubations. Bars give the SEM. Control values in the absence of hormone have been subtracted. (See legend to Fig. 1) 
is resistant to phosphodiesterase cleavage and it may enter the cell more easily than cyclic AMP [20]. This might explain why it is more effective than cyclic AMP in stimulating lipolysis. Its mechanism of action within the cell may be mediated by its degradation product $\mathrm{N}^{6}$-monobutyryl cyclic AMP [21] or by phosphodi- esterase inhibition resulting in an increase of intracellular cyclic AMP [22]. Fig. 5 shows that in both tissues half-maximal stimulation of lipolysis occurs at similar concentrations of the cyclic nucleotide derivative, although at concentrations below $1 \mathrm{mM}$ diabetic tissue appears even less sensitive than normal tissue.
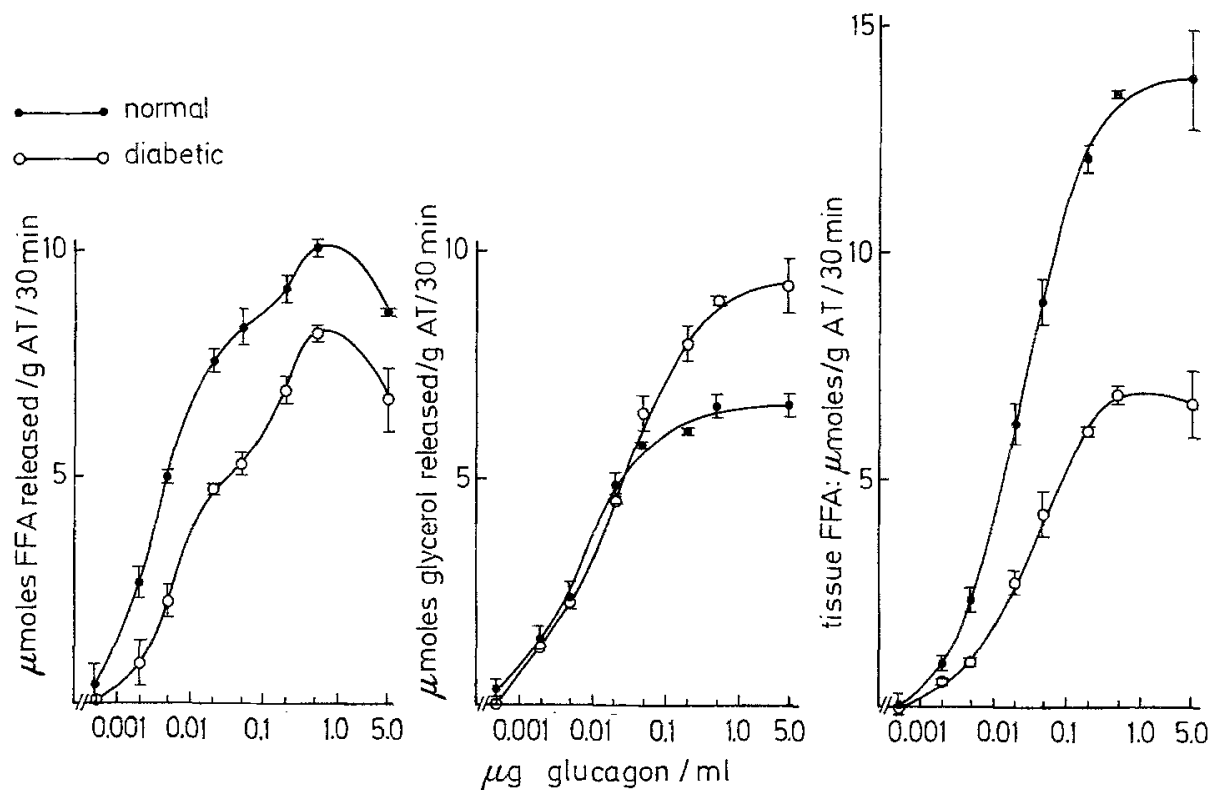

Fig. 4. Dose-response curves of glucagon-stimulated lipolysis in adipose tissue of normal and streptozotocin-diabetic rats: Incubations were performed for $30 \mathrm{~min}$ at $37^{\circ} \mathrm{C}$ after hormone additions preceded by a 1 hour preincubation period in the absence of glucagon. Each point represents the mean value of 4 incubations. Bars give the SEM. Control values in the absence of hormone have been subtracted. (See legend to Fig. 1)

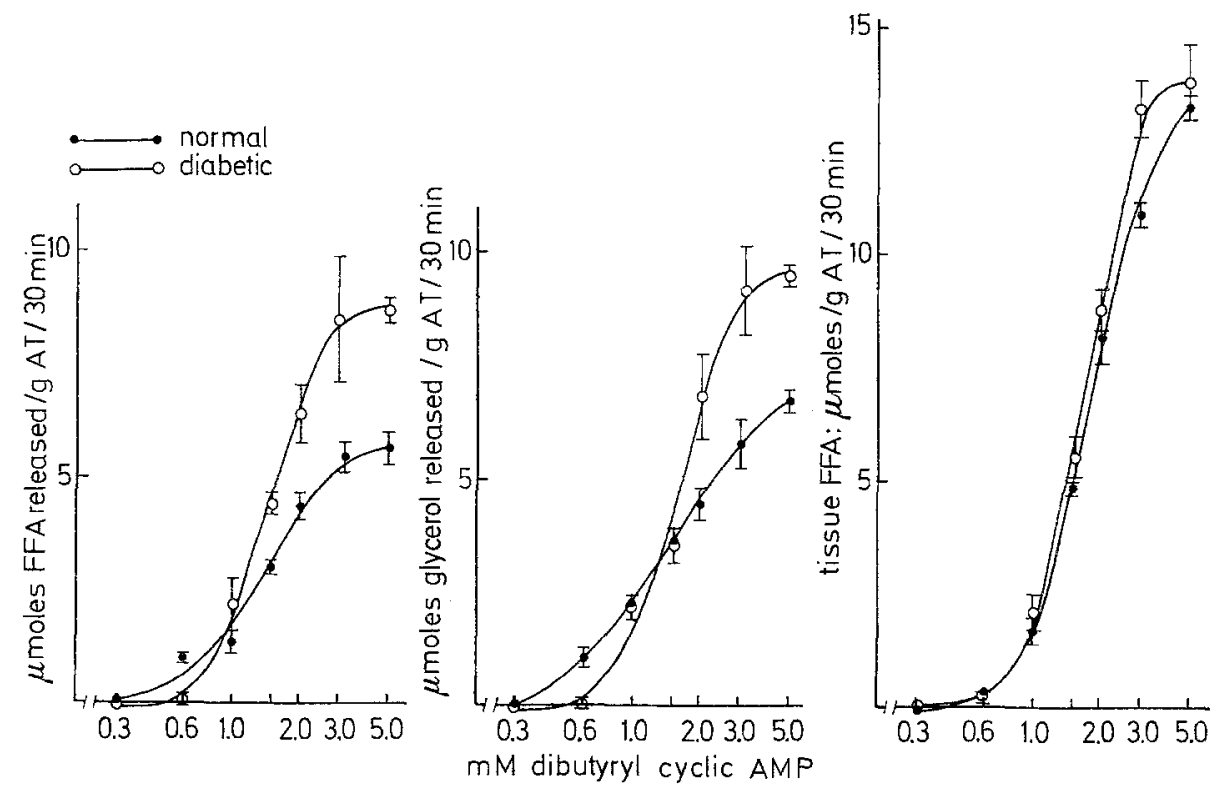

Fig. 5. Dose-response curves of dibutyryl cyclic AMP-stimulated lipolysis in adipose tissue of normal and streptozotocin-diabetic rats: Incubations were carried out for $30 \mathrm{~min}$ at $37^{\circ} \mathrm{C}$ after addition of different amounts of dibutyryl cyclic AMP preceded by a 1 hour preincubation in the absence of the cyclic nucleotide derivative. Each point represents the mean of 4 incubations. Bars give the SEM.

Control values in the absence of dibutyryl cyclic AMP have been subtracted. (See legend to Fig. 1) 


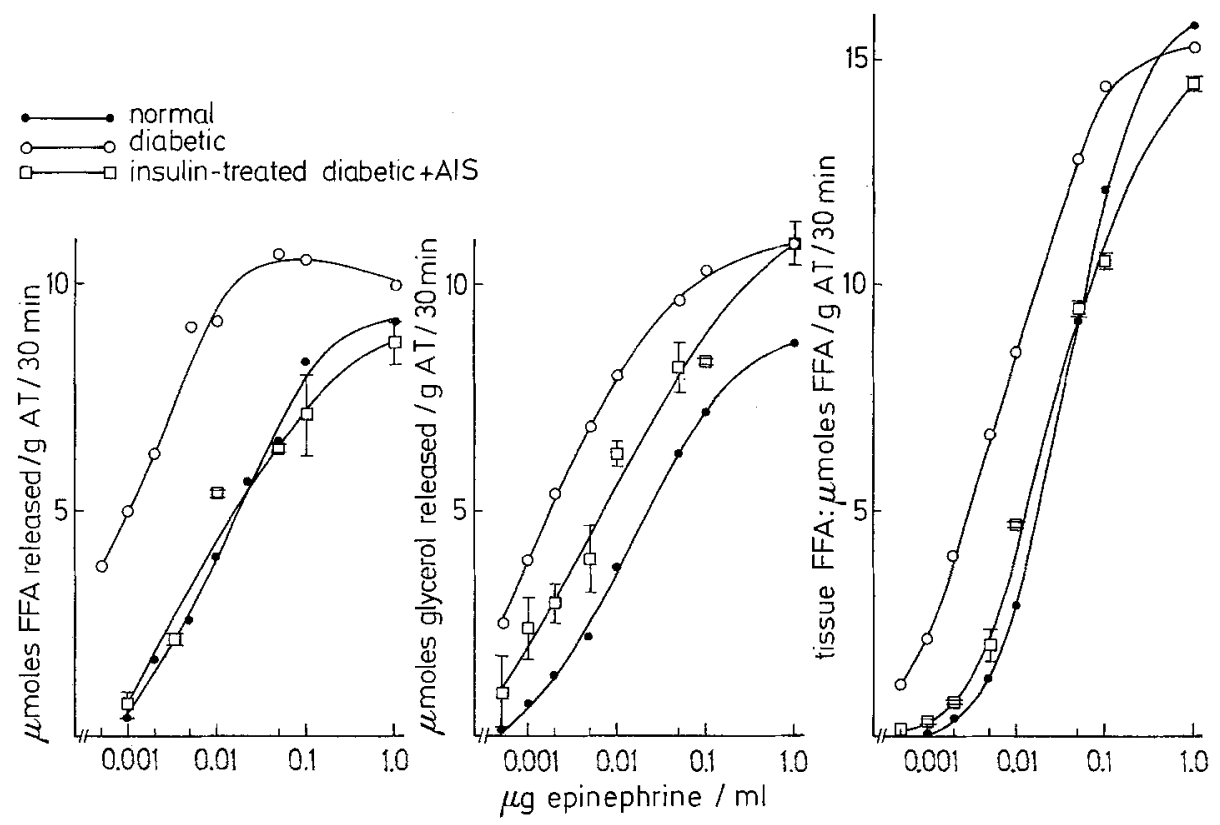

Fig. 6. Dose-response curves of epinephrine-stimulated lipolysis in adipose tissue of normal, diabetic and insulin-treated ( $5 \times 2 \mathrm{U} / \mathrm{rat} / 24$ h) diabetic rats: Adipose tissue of insulin-treated diabetic rats was incubated in the presence of $10 \mu \mathrm{l}$ of anti-insulin serum (AIS) neutralizing $10 \mathrm{mU}$ of insulin. The points of this dose-response curve represent mean values of four determinations and bars give the SEM. Dose-response curves for normal and diabetic adipose tissue are the same as in Fig. 1, except that the SEM's have been left out for clearness of the graph
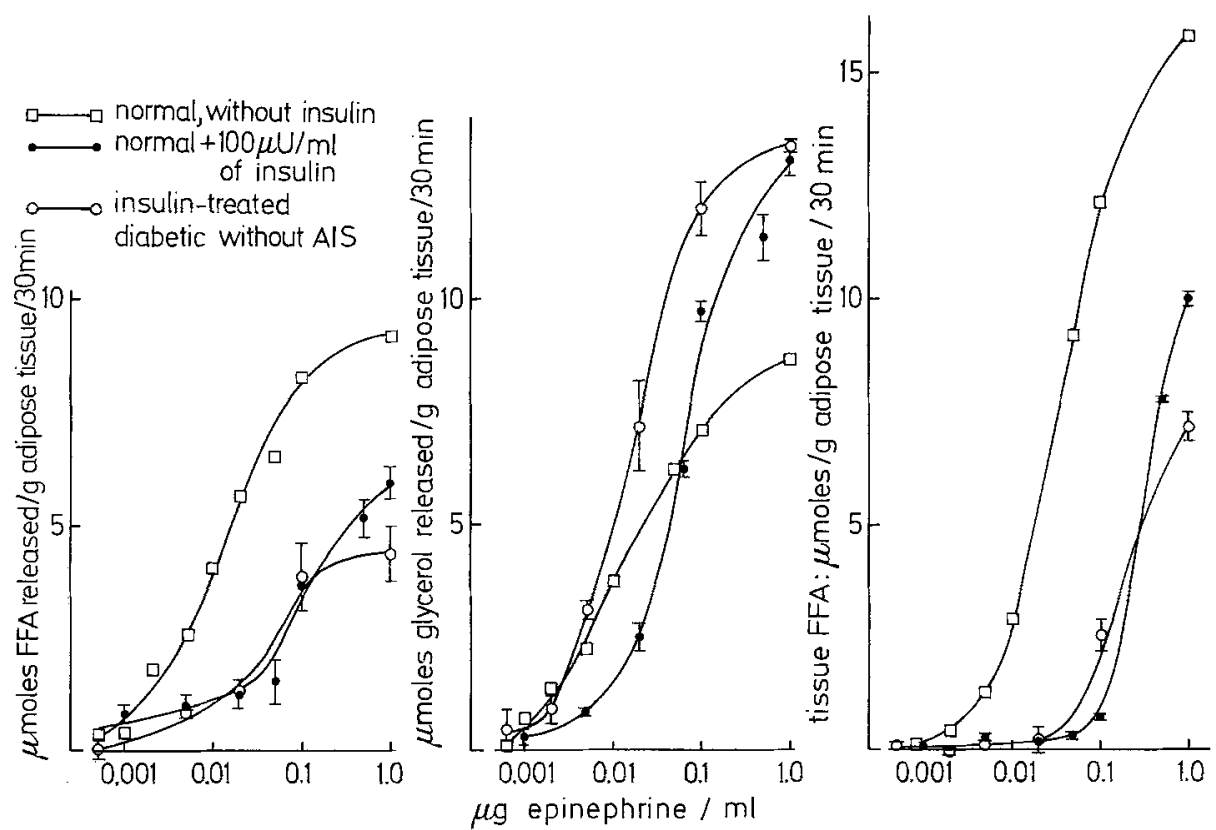

Fig. 7. Dose-response curves of epinephrine-stimulated lipolysis of normal adipose tissue in the absence and presence of $100 \mu \mathrm{U} / \mathrm{ml}$ of insulin and of adipose tissue from insulin-treated diabetic rats in the absence of anti-insulin serum (AIS). Incubations, hormone additions and determination of glycerol and FFA were carried out as described in the preceding figures. All points give the mean of 4 incubations. Bars represent the SEM. In contrast to Fig. 6 adipose tissue of insulin-treated diabetic rats was incubated in the absence of anti-insulin serum (AIS) to demonstrate that 2-3 hrs after insulin treatment considerable amounts of insulin still adhere to the tissue and counteract the stimulatory effect of epinephrine. For normal adipose tissue in the absence of insulin the dose-response curves are the same as in Fig. 1 except that the SEM is omitted 
The effect of insulin treatment of streptozotocindiabetic rats on the lipolytic response of adipose tissue to epinephrine is demonstrated in Fig. 6. Preincubation of the tissue was carried out in the presence of $10 \mu \mathrm{l}$ of guinea pig anti-insulin serum neutralizing 10 $\mathrm{mU}$ of insulin. Anti-insulin serum was included in this assay because considerable amounts of insulin seemed to adhere to adipose tissue of insulin-treated diabetic rats 2-3 hrs after the last insulin injection plus one hour of preincubation. These remaining amounts of insulin significantly counteracted epinephrine stimulation, and the dose-response curve was very similar to the one obtained with normal tissue in the presence of $100 \mu \mathrm{U} / \mathrm{ml}$ of insulin (Fig. 7). In normal tissue $10 \mathrm{mU}$ of anti-insulin serum had no effect on the lipolytic response at any epinephrine concentration tested (not shown).

After $24 \mathrm{hrs}$ of insulin treatment FFA release and the response of tissue FFA to epinephrine in the presence of anti-insulin serum were restored to normal, whereas the response of glycerol release was between that of the tissue from normal and that from untreated diabetic rats (Fig. 6). From these results it may be concluded that after insulin treatment stimulation of lipolysis by epinephrine was still enhanced, but compensated by an increased re-esterification rate. This condition is similar to basal lipolysis in adipose tissue from fasted-refed rats [23].

\section{Discussion}

Increased sensitivity of the lipolytic response to hormones may be caused by a mechanism operative

1. at the cell membrane level by increased hormone-receptor binding [24] and/or increased stimulus generation via the adenylate cyclase system $[17,24]$, resulting in increased cyclic AMP formation $[16,18$, 19].

or 2 . inside the cell, i. e. beyond hormone-receptor interaction; this could imply that cyclic AMP-degradation by phosphodiesterase is decreased or that protein kinase and/or triglyceride lipase are more sensitive to activation $[25,26]$.

Evidence in favour of the first possibility was obtained by the results of the experiments described in Figs. 1, 3, 4 and 5: They show that the sensitivity of diabetic adipose tissue to ACTH and glucagon is decreased rather than increased compared to normal tissue (Figs. 3, 4). This is in striking contrast to the considerably enhanced lipolytic response of diabetic fat pads to epinephrine (Fig. 1)

These results are consistent with the present concept of the specificity of hormone action, which postulates different discriminators on the cell membrane coupled with membrane-bound adenylate cyclase [17,
24]. Furthermore, they speak against the possibility that the affinity of phosphodiesterase to cyclic AMP is reduced in diabetic adipose tissue, unless there exist hormone specific phosphodiesterases coupled to their respective receptors. Although this would be an attractive hypothesis there is no evidence for it at present.

It has been reported that phosphodiesterase activity is decreased in diabetic adipose tissue [27]. However, a decrease of phosphodiesterase activity should result in an increased lipolytic response to all three hormones, which was not the case. As demonstrated in Fig. 5, in both tissues half-maximal stimulation of the three lipolytic indices is elicited by similar concentrations of dibutyryl cyclic AMP. Assuming that the cyclic nucleotide derivative acts like cyclic AMP itself intracellularly [see page 7 and (21) (22)], the latter results indicate that the sensitivity of protein kinase and of triglyceride mobilizing lipase to activation is not increased in diabetic fat pads.

Therefore, these findings suggest that insulin deficiency renders the adenylate cyclase-coupled catecholamine receptor of adipose tissue either more sensitive or more accessible to the action of the hormone.

Enhanced sensitivity of lipolysis towards epinephrine can also be demonstrated in adipose tissue of fasted rats (Zapf, Waldvogel, Froesch, in preparation). In addition, insulin treatment of diabetic rats restores the lipolytic response to epinephrine to near normal (Fig. 6). Plasma insulin levels seem, therefore, to play an important direct or indirect role in the regulation of the sensitivity of rat adipose tissue to catecholamines.

Hypersensitivity towards sympathomimetic amines has been observed in a variety of adrenergically innervated organs both in vivo and in vitro $[28,29,30,31]$. It has been attributed essentially to two mechanisms, 1. impaired net uptake of the sympathomimetic amine into the sympathetic nerve endings (presynaptic) resulting in a higher hormone concentration at the receptor sites or 2 . a change in the affinity ("deformation") of the end organ receptor towards the amine (postsynaptic) (for review see 28).

Such a change in affinity could be simulated by an increase of the receptor reserve [32]. It might result from a relative increase of catecholamine receptors per surface area as a consequence of the shrinkage of the fat pads during diabetes. However, the same would be expected also for ACTH and glucagon receptors, but diabetic adipose tissue proves even less sensitive to these two hormones. Furthermore, since $24 \mathrm{hr}$ insulin treatment does not restore diabetic fat pads to their normal size and weight, whereas it almost completely restores the responsiveness to epinephrine (Fig. 6), increased receptor reserve is not likely to be responsible for enhanced sensitivity to this 
hormone. Preliminary experiments with isoproterenol, which is not taken up into nerve endings [33], indicate that hypersensitivity of diabetic adipose tissue to epinephrine is due mainly to a change in the affinity of the catecholamine receptor-adenylate cyclase system.

Enhanced sensitivity of diabetic adipose tissue to epinephrine also accounts for our finding that insulin is less effective in inhibiting epinephrine-induced lipolysis in diabetic than in normal fat pads (Fig. 2). Although we have no evidence that our results also apply to in vivo conditions or to diabetes in man they might provide an additional explanation for increased FFA mobilization in the diabetic state, and they point to a possible role of the autonomic nervous system in the regulation of lipolysis during insulin dificiency.

\section{References}

1. Havel, R. J.: Autonomic nervous system and adipose tissue. In: Handbook of Physiology, Section V. Adipose tissue (eds. A. E. Renold, G. F. Cahill, Jr.), p. 577. Washington D. C. 1965

2. Winegrad, A. I.: Adipose tissue in diabetes. In: Handbook of Physiology, Section V. Adipose tissue (eds. A. E. Renold, G. F. Cahill, Jr.), pp. 324-328. Washington D. C. 1965

3. Biermann, E. L., Dole, V.P., Roberts, T. N.: An abnormality of nonesterified fatty acid metabolism in diabetes mellitus. Diabetes 6, 475-479 (1957)

4. Dole, V. P.: Fat metabolism in diabetes. Bull. N. Y. Acad. Med. 34, 21-25 (1958)

5. Vaughan, M.: The metabolism of adipose tissue in vitro. J. Lipid Res. 2, 293-316 (1961)

6. Rizack, M. A.: An epinephrine-sensitive lipolytic activity in adipose tissue. J. biol. Chem. 236, 657-662 (1961)

7. Wieland, O., Suyter, M.: Glycerokinase. Isolierung und Eigenschaften des Enzymes. Biochem. Z. 329, 320-331 (1957)

8. Shapiro, B., Chowers, I., Rose, G.: Fatty acid uptake and esterification in adipose tissue. Biochim. biophys. Acta (Amst.) 23, $115-120$ (1957)

9. Froesch, E. R.: Fructose metabolism in adipose tissue from normal and diabetic rats. In: Handbook of Physiology, Section V. Adipose tissue (eds. A. E. Renold, G. F. Cahill, Jr.), pp. 281-293. Washinton D. C. 1965

10. Meyer, U. A., Sturzenegger, V., Froesch, E. R.: Transport and metabolism of glucose, insulin sensitivity and lipolysis of epididymal adipose tissue of alloxan-diabetic rats after prolonged incubation in vitro. Diabetologia 4, 87-94 (1968)

11. Froesch, E. R., Bürgi, H., Ramseier, E. B., Bally, P., Labhart, A.: Antibody-suppressible and nonsuppressible insulin-like activities in human serum and their physiologic significance. An insulin assay with adipose tissue of increased precision and specificity. J. clin. Invest. 42, 1816-1834 (1963)

12. Duncombe, W. G.: The colorimetric microdetermination of longchain fatty acids. Biochem. J. 88, 7-10 (1963)

13. Angel, A., Desai, K. S., Halperin, M. L.: Intracellular accumulation of free fatty acids in isolated white adipose cells. J. Lipid Res. 12, 104-111 (1971)

14. Eggstein, M., Kreutz, F. H.: Eine neue Bestimmung der Neutralfette im Blutserum und Gewebe. Klin. Wschr. 44, 262-267 (1966)

15. Jungas, R. L., Ball, E. G.: Studies on the metabolism of adipose tissue. XII. The effects of insulin and epinephrine on free fatty acid and glycerol production in the presence and absence of glucose. Biochemistry 2, 383-388 (1963)

16. Butcher, R. W., Baird, C. E., Sutherland, E. W.: Effects of lipolytic and antilipolytic substances on adenosine 3'5'-monophosphate levels in isolated fat cells. J. biol. Chem. 243 , No. 8, 1705-1712 (1968)

17. Braun, T., Hechter, O.: Glucocorticoid regulation of ACTH sensitivity of adenyl cyclase in rat fat cell membranes. Proc. nat. Acad. Sci. (Wash.) 66, No. 3, 995-1001 (1970)

18. Butcher, R. W.: Cyclic 3', 5' AMP and the lipolytic effects of hormones in adipose tissue. Pharmacol. Rev. 18, 237-241 (1966)

19. Butcher, R. W., Sneyd, J. G. T., Park, C. R., Sutherland, E. W.: Effect of insulin on adenosine 3', 5'-monophosphate in the rat epididymal fat pad. J. biol. Chem. 241, 1651-1653 (1966)

20. Butcher, R. W.: Cyclic AMP, lipolysis and antilipolysis. In: Adipose tissue, regulation and metabolic functions (eds. B. Jeanrenaud, D. Hepp), p. 6. Stuttgart: Georg Thieme Verlag, New York-London: Academic Press 1970

21. Kaukel, E., Mundhenk, K., Hilz, H.: $\mathrm{N}^{6}$-monobutyryladenosine $3^{\prime}: 5$ '-monophosphate as the biologically active derivative of dibutyryladenosine 3':5' monophosphate in HeLa 53 cells, Europ. J. Biochem. 27, 197-200 (1972)

22. Jarett, L., Steiner, A. L., Smith, R. M., Kipnis, D. M.: The involvement of cyclic AMP in the hormonal regulation of protein synthesis in rat adipocytes. Endocrinology 90, 1277-1284 (1972)

23. Froesch, E. R., Bürgi, H., Bally, P., Labhart, A.: Insulin inhibition of spontaneous adipose tissue lipolysis and effects upon fructose and glucose metabolism. Molec. Pharmacol. 1, No. 3, 280-296 (1965)

24. Birnbaumer, L., Rodbell, M.: Adenyl cyclase in fat cells. II. Hormone receptors. J. biol. Chem. 244, No. 13, 3477-3428 (1969)

25. Soderling, T. R., Corbin, J. D., Park, C. R.: Regulation of adenosine 3', 5'-monophosphate-dependent protein kinase. II. Hormonal regulation of the adipose tissue enzyme. J. biol. Chem. 248, No. 2, 1822-1829 (1973)

26. Huttunen, J. K., Steinberg, D.: Activation and phosphorylation of purified adipose tissue hormone-sensitive lipase by cyclic AMP-dependent protein kinase. Biochim. biophys. Acta (Amst.) 239, 411-427 (1971)

27. Senft, G., Schultz, G., Munske, K., Hoffmann, M.: Influence of insulin on cyclic 3', 5'-AMP phosphodiesterase activity in liver, skeletal muscle, adipose tissue and kidney. Diabetologia 4, 322-329 (1968)

28. Trendelenburg, U.: Supersensitivity and subsensitivity to sympathomimetic amines. Pharmacol. Rev. 15, 225-276 (1963)

29. Trendelenburg, U.: Mechanisms of supersensitivity and subsensitivity to sympathomimetic amines. Pharmacol. Rev. 18, 629-640 (1967)

30. Deguchi, T., Axelrod, J.: Superinduction of serotonin-N-acetyltransferase and supersensitivity of adenylcyclase to catecholamines in denervated pineal gland. Molec. Pharmacol. 9, 612-618 (1973)

31. Rosell, S., Belfrage, E.: Adrenergic receptors in adipose tissue and their relation to adrenergic innervation. Nature 253, 738-739 (1975)

32. Rudinger, J., Pliška, V., Krejči, I.: Oxytocin analogs in the analysis of some phases of hormone action. Rec. Progr. Horm. Res. 28, 131-166 (1972)

33. Hertting, G.: The fate of ${ }^{3} \mathrm{H}$-isoproterenol in the rat. Biochem. Pharmacol. 13, 1119-1128 (1964)

Dr. J. Zapf

Kantonsspital Zürich

Dept. für Innere Medizin

Medizinische Klinik

Stoffwechsellabor

Rämistraße 100

CH-8006 Zürich

Switzerland 